Davies, M. E. (1954). J. gen Microbiol. 11, 37-44.

\title{
A Study of the Diffusible Lipase produced by Staphylococci and of its Immunological Activity
}

\author{
By M. ELIZABETH DAVIES* \\ Department of Bacteriology, Postgraduate Medical School of London
}

SUMMARY : A systematic investigation of eighteen genera showed that staphylococei were the only potentially pathogenic group which produced a diffusible lipase detectable on solid culture medium. This lipase was obtained in filtrates of cultures grown by a well-established method for preparing staphylococcal toxins. When titrated, filtrates of very active strains showed lipolytic activity in dilutions of $\mathbf{1 / 4 0 9 6}$, but the majority of strains had a titre of $1 / 256$.

Whole cultures and culture filtrates of albus strains and formolized filtrates of aureus strains were found to stimulate the production of anti-lipolytic antibody in rabbit serum. The titre of the most active antiserum was $1 / 40$, and that of the majority 1/10. Each antiserum prepared showed maximal neutralizing activity against the homologous filtrate, but all antisera studied neutralized heterologous filtrates to some extent. No evidence of naturally occurring anti-lipolytic antibody was found in any of the rabbit sera used.

A considerable amount of work has been done on the lipolytic activity of micro-organisms concerned in food-spoilage, but relatively little on that of potential pathogens. Among the earliest workers were Escherisch (1886) and Nencki (1886), from whose observations numerous subsequent workers developed techniques to demonstrate the ability of micro-organisms to hydrolyse a wide range of fatty substrates; much of this work was reviewed by Jensen \& Grettie (1937). The majority of organisms produced either the exo-lipase or the endo-lipase but some strains produced both types. The type of enzyme studied depended upon the technique used, the activity of endo-enzymes being demonstrated when physico-chemical treatment of the bacterial cells was employed, and that of exo-enzymes by culture methods with living cells. In the present work investigations were limited to the exo-lipases. A systematic survey covering over 1000 strains of eighteen genera showed that, among potentially pathogenic groups, only the staphylococci produced a diffusible or exo-lipase.

\section{MATERIALS AND METHODS}

Solid media were found to be more sensitive than fluid ones for demonstrating lipolytic activity of growing bacteria.

Fat emulsion. Horse fat was used because, in fatty-acid composition, it resembled human fat more closely than any other mammalian fat available (Hilditch, 1947). The emulsion was prepared from the following : horse fat $4.0 \mathrm{ml}$; ; 6.0 $\%(\mathrm{w} / \mathrm{v})$ aqueous agar $3.0 \mathrm{ml}$; d distilled water $93.0 \mathrm{ml}$. The melted fat and aqueous agar were mixed and boiling water added gradually, the mixture being passed repeatedly through a hand-driven domestic mechanical

* Present address: The Canine Research Station, Kennett, near Newmarket, Suffolk. 
emulsifier ('Cream Maker, Empire Series', British Emulsifiers Ltd., Greek Street, London, W.1).

Nutrient fat agar (N.F.A.) was prepared by adding an emulsion of horse fat to beef infusion agar $\mathrm{pH} 7 \cdot 2-7 \cdot 4$, to give a final concentration of fat $0 \cdot 3 \%(\mathrm{w} / \mathrm{v})$. $7.5 \mathrm{ml}$. emulsion was added to $\mathbf{9 2 . 5} \mathrm{ml}$. melted agar. Twenty-five ml. of medium were poured into Petri dishes $(7 \cdot 0 \mathrm{~cm}$. diam.) which were dried for $1 \mathrm{hr}$. before use. On this medium lipolytic activity was shown by a zone of clearing round the colony (Pl. 1, fig. 1).

Nutrient fat Nile Blue sulphate agar (N.B.S.A.). This medium differed from N.F.A. above only in containing $2.0 \mathrm{ml}$. aqueous $0.1 \%(\mathrm{w} / \mathrm{v})$ Nile Blue sulphate to every $100 \mathrm{ml}$. N.F.A. Nile Blue sulphate is an oxazine dye and is pink in the presence of neutral fat and blue with free fatty-acids (Kaufmann \& Lehmann, 1926; Rettie, 1931; Knaysi, 1941; Govan, 1944). It was first used in media for observing lipolysis by Turner (1929). Strains which showed positive results . on this medium produced a blue-coloured colony surrounded by a clear blue zone. Strongly positive strains produced a bright blue colour and a wide surrounding zone, while less active strains produced a paler colour and a narrower zone. This medium was found to be better than N.F.A. for studying culture filtrates.

Strains of staphylococci. Eighty-eight strains were studied, forty-eight of Staphylococcus aureus of which forty-one $(\mathbf{8 5} \cdot 4 \%$ ) were lipolytic, thirtyeight of $S$. albus of which twenty-nine $(76.3 \%)$ were lipolytic, and two of $S$. citreus of which one was lipolytic. Twenty-five of the $S$. aureus strains had been associated with outbreaks of food-poisoning and were obtained by the courtesy of Dr R. E. O. Williams (London) and Dr J. Marks (Cardiff). All other strains were isolated from pathological materials.

Control strains of bacteria. Several strains of Escherichia coli were used as negative controls during the isolation of lipolytic staphylococci. Non-lipolytic staphylococci were used when investigating staphylococcal lipase in culture filtrates.

Preparation of culture filtrates. The method recommended by Mackie \& McCartney (1948) for the preparation of staphylococcal toxin was used. Semisolid agar (agar $0.8 \%, \mathrm{w} / \mathrm{v}$ ), $25 \mathrm{ml}$. in $250 \mathrm{ml}$. conical flasks, was inoculated with $5.0 \mathrm{ml}$. of $24 \mathrm{hr}$. broth culture and incubated at $37^{\circ}$ in an atmosphere of $25 \%$ carbon dioxide for 3 days. Buffered peptone broth containing $3 \%(w / v)$ peptone was added in the proportion of $5.0 \mathrm{ml}$. broth to $25 \mathrm{ml}$. semi-solid agar, and the flasks reincubated as before for a further 3 days. Cultures were harvested by filtering first through paper then through Chamberland filter candles.

Lipolytic activity of culture filtrates. This was tested by using N.B.s.A. and porcelain cylinders, according to the method of Heatley (1944). Five cylinders were fixed to each plate, the central position being reserved for the control fluid which had been heated at $85^{\circ}$ for $45 \mathrm{~min}$. During incubation at $37^{\circ}$ the filtrate diffused from the cylinders and produced blue zones after $18 \mathrm{hr}$. of incubation. No zones were formed by the heated control fluids. When N.F.A. medium was used instead of N.B.s.A. corresponding colourless zones were 


\section{Diffusible lipase of staphylococci}

formed, but were much less distinct. As incubation proceeded, up to $96 \mathrm{hr}$., the zones enlarged and concentric rings formed. The zones produced by all active filtrates showed a comparable pattern in their concentric rings. The central ring, or area immediately round the cylinder, was deep blue, relatively opaque and sometimes showed precipitation resembling the deposition of fatty-acid crystals. The ring immediately surrounding this area was clear and transparent, usually violet in colour but sometimes colourless. In some cases this ring divided into two, of which one was blue in colour. The third ring was always the narrowest, and was clear and colourless or had a pale pink tint. Sometimes another poorly defined colourless ring developed outside the narrow one (Pl. 1, fig. 2).

Titration of culture filtrates. Filtrates and dilutions up to 1/4096 were dropped from calibrated dropping pipettes $(50 \mathrm{drops} / \mathrm{ml}$.) over the surface of N.B.S.A. plates resting on a ruled template. When the drops were absorbed the plates were incubated at $37^{\circ}$ for $48 \mathrm{hr}$. Zones of colour were formed and differentiated into concentric rings similar to those observed when porcelain cylinders were used. The titre of a filtrate was arbitrarily selected as that dilution which just failed to show differentiation into concentric rings after the plate had been incubated for $48 \mathrm{hr}$. This end-point was nearly always some 4-8 times the lowest dilution which showed demonstrable lipolysis. In the lower dilutions there was little variation in the size of the zones, but as the dilution approached the end-point, the size and intensity tended to decrease. The average of triplicate titrations was taken as the titre.

Properties of staphylococcal lipase. The optimal period for production of lipolytic culture filtrates was found by incubating the cultures for periods varying from 6 to 20 days. The optimal medium was found by growing strains in five batches of beef infusion broth, each of which gave a different final $\mathrm{pH}$ value after the growth of the same organism. The effect of the volume of medium on the production of lipase was studied by comparing the activity of filtrates from small volumes $(25 \mathrm{ml}$.) with those of the same strains grown in large volumes of medium (500 ml.). The value of carbon dioxide was investigated by growing cultures ( $25 \mathrm{ml}$. medium), with and without increased carbon dioxide tension. The presence of a precursor for lipase, as observed by Elliott $(1945,1950)$ for streptococcal proteinase, was investigated by decreasing the incubation time to 24 and $48 \mathrm{hr}$. Cultures were prepared in triplicate, and in two sets the $\mathrm{pH}$ value of the medium was varied by adding glucose in final concentrations of 0.5 and $1.0 \%$, the buffered peptone being omitted. The filtrates of these cultures were divided into two parts and $0.1 \%$ sodium mercaptoacetate (thioglycollate) added to one portion of each. Each portion was then divided again and one half stored at $4^{\circ}$ and the other at room temperature for 1 week. All were then retested for lipolytic activity. The heat stability of staphylococcal lipase was measured by holding filtrates at different temperatures in a water-bath for varying periods of time. The activity was then assayed on N.B.S.A. as described above. The temperatures used were $56,70,85$ and $100^{\circ}$. The stability on storage was measured by keeping filtrates at $4^{\circ}$ for 9 months and assaying the lipolytic activity every few weeks. 
Production of anti-lipolytic antibody in rabbits. Before inoculation all rabbits were bled from the ear and their sera examined for naturally occurring antilipolytic antibody. Two methods of immunization were used. (a) Living cultures of albus strains; $24 \mathrm{hr}$. digest broth cultures diluted 1/10 were injected intravenously into rabbits in increasing doses $(0 \cdot 1-0 \cdot 4 \mathrm{ml}$.) on successive days, followed by 4 days of rest. This course was repeated a week later and in two subsequent weeks when undiluted cultures were used. Samples of serum were taken 4 days after the last injection. Three rabbits were used for each strain. (b) Culture filtrates of aureus and albus strains; filtrates were inoculated intravenously on 3 successive days followed by 4 days of rest, for 4 weeks, doses being increased gradually from 0.1 to $1.0 \mathrm{ml}$. The toxin present in filtrates of aureus strains was converted to toxoid by the method of Dolman \& Kitching (1935).

Titration of immune rabbit serum for anti-lipolytic activity. Serial dilutions of the homologous filtrate were dropped on to N.B.S.A. plates and drops of immune serum, undiluted and diluted $1 / 5$ to $1 / 40$, were added immediately before the filtrate had been absorbed into the medium. The filtrate and serum drops were mixed and after absorption into the agar, the plates were incubated as for titration of filtrates. Duplicate plates were used in all titrations of anti-lipolytic activity. Two controls were used, corresponding dilutions of the filtrate alone, and filtrate mixed with undiluted normal rabbit serum (Pl. 1, fig. 3).

\section{RESULTS}

Satisfactory results in the isolation of lipolytic staphylococci were obtained using N.F.A. medium, which was preferable to N.B.s.A. for cultures because it eliminated the 'false positive' results described by Turner (1929). N.B.s.A., however, was found preferable to N.F.A. for culture filtrates of lipolytic strains as the dye appeared to sharpen the definition of the zones.

Compared with albus strains of staphylococci more aureus strains were found to produce diffusible lipase (Table 1). When other biochemical activities (sugar fermentations, production of coagulase, haemolysis on blood agar) were investigated, it was found that in general lipolytic strains tended to be more active biochemically than non-lipolytic ones (Table 2 ).

Lipase was demonstrable in culture filtrates only when staphylococci were grown in conditions known to be required for the formation of other toxins, notably the $\alpha, \beta$ and $\gamma$ haemolysins, although the presence of these toxins in the filtrates prepared was not investigated.

Staphylococcal lipase proved to be relatively stable in culture filtrates c. $\mathrm{pH} \mathrm{8,} \mathrm{filtrates} \mathrm{of} \mathrm{aureus} \mathrm{strains} \mathrm{being} \mathrm{slightly} \mathrm{more} \mathrm{stable} \mathrm{than} \mathrm{those} \mathrm{from}$ albus strains. Approximately half of the activity was lost by heating for $1 \mathrm{hr}$. at $70^{\circ}$ or for $45 \mathrm{~min}$. at $85^{\circ}$; boiling for $40-50 \mathrm{~min}$. destroyed the activity completely. With the majority of strains, only a very gradual loss of lipolytic activity from the culture filtrates was observed during storage at $4^{\circ}$ for 9 months; this was apparent more by loss of differentiation of zones than by a decrease in their diameter. 
Table 1. Staphylococci tested for the production of diffusible lipase

\begin{tabular}{|c|c|c|c|c|c|}
\hline \multirow[b]{2}{*}{ Species } & \multirow{2}{*}{$\begin{array}{l}\text { No. of } \\
\text { strains } \\
\text { tested }\end{array}$} & \multicolumn{2}{|c|}{$\begin{array}{l}\text { No. of lipolytic } \\
\text { strains }\end{array}$} & \multicolumn{2}{|c|}{$\begin{array}{l}\text { No. of non-lipolytic } \\
\text { strains }\end{array}$} \\
\hline & & $\begin{array}{l}\text { Coagulase } \\
\text { positive }\end{array}$ & $\begin{array}{c}\text { Coagulase } \\
\text { negative }\end{array}$ & $\begin{array}{l}\text { Coagulase } \\
\text { positive }\end{array}$ & $\begin{array}{c}\text { Coagulase } \\
\text { negative }\end{array}$ \\
\hline S. aureus & 48 & 39 & 2 & 5 & ' 2 \\
\hline S. albus & 38 & 11 & 18 & 3 & 6 \\
\hline S. citreus & 2 & 1 & 0 & 0 & 1 \\
\hline
\end{tabular}

Table 2. Comparison between the production of diffusible lipase by staphylococci and some other biochemical activities

\begin{tabular}{|c|c|c|c|c|c|}
\hline & $\begin{array}{l}\text { No. of } \\
\text { strains } \\
\text { tested }\end{array}$ & $\begin{array}{c}\text { No. of } \\
\text { sugars } \\
\text { fermented }\end{array}$ & $\begin{array}{c}\text { No. of } \\
\text { strains } \\
\text { producing } \\
\text { coagulase }\end{array}$ & $\begin{array}{c}\text { No. of } \\
\text { strains } \\
\text { liquefying } \\
\text { gelatin }\end{array}$ & $\begin{array}{c}\text { No. of } \\
\text { strains } \\
\text { haemolytic on } \\
\text { blood-agar }\end{array}$ \\
\hline Lipolytic strains & 42 & $6 / 12$ & 38 & 33 & 32 \\
\hline Non-lipolytic strains & 8 & $\begin{array}{c}\text { Fewer than } \\
6 / 12\end{array}$ & 1 & $\mathbf{0}$ & 2 \\
\hline
\end{tabular}

Table 3. Anti-lipolytic activity of normal and immune rabbit serum against the homologous filtrate

Filtrate

S. aureus W3

S. albus 8
Serum

\begin{tabular}{l}
\multicolumn{1}{c}{0} \\
Normal \\
Immune W3 \\
Immune W3 \\
Immune W3 \\
Immune W3 \\
Immune W 3
\end{tabular}

0
Normal

Immune 8

Immune 8

Immune 8

Immune 8

Immune 8

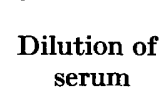

Maximum dilution of filtrate showing lipolysis

$1 / 1$

$1 / 512$

$1 / 1 \quad 1 / 4$

$1 / 5 \quad 1 / 16$

$1 / 10 \quad 1 / 32$

$1 / 20 \quad 1 / 128$

$1 / 40 \quad 1 / 256$

- $1 / 256$

$1 / 1 \quad 1 / 256$

$1 / 1 \quad 1 / 4$

$1 / 5 \quad 1 / 32$

$1 / 10 \quad 1 / 64$

$1 / 20 \quad 1 / 128$

$1 / 40 \quad 1 / 128$

Table 4. Anti-lipolytic activity of four rabbit antisera against homologous and heterologous filtrates

Titre of filtrate after mixing with undiluted anti-lipolytic serum

\begin{tabular}{|c|c|c|c|c|c|c|c|c|}
\hline \multirow[b]{2}{*}{ Antiserum } & \multicolumn{4}{|c|}{ Filtrates from aureus strains } & \multicolumn{4}{|c|}{ Filtrates from albus strains } \\
\hline & $\begin{array}{c}\text { W3 } \\
(1 / 256)\end{array}$ & $\begin{array}{c}\text { W4 } \\
(1 / 128)\end{array}$ & $\begin{array}{c}\text { M3 } \\
(1 / 64)\end{array}$ & $\begin{array}{c}\text { M5 } \\
(1 / 128)\end{array}$ & $\begin{array}{c}8 \\
(1 / 128)\end{array}$ & $\begin{array}{c}16 \\
(1 / 32)\end{array}$ & $\begin{array}{c}20 \\
(1 / 32)\end{array}$ & $\begin{array}{c}39 \\
(1 / 64)\end{array}$ \\
\hline W3 & $\mathbf{U}$ & - & - & - & $\mathbf{U}$ & $1 / 4$ & - & - \\
\hline W4 & $1 / 2$ & - & $\mathbf{U}$ & $\mathbf{U}$ & - & $1 / 2$ & $1 / 2$ & $\mathbf{U}$ \\
\hline 8 & $1 / 2$ & - & $1 / 2$ & $\mathbf{U}$ & - & $\mathbf{U}$ & $1 / 4$ & $1 / 2$ \\
\hline 39 & $1 / 8$ & - & $1 / 4$ & $\mathbf{U}$ & - & $1 / 2$ & $\mathbf{U}$ & - \\
\hline
\end{tabular}

Initial titre of culture filtrate in brackets ; - , lipolytic activity of filtrate neutralized completely; $U$, lipolytic activity of filtrate neutralized except in the undiluted state. 
Antibody was formed readily in rabbits, none of the strains studied failing to stimulate antibody production. No difference was observed in the antigenicity of albus strains and culture filtrates of the same strains; all antisera neutralized the lipolytic activity of the homologous filtrate and also that of a wide range of heterologous filtrates, in many cases to a comparable degree. Examples of the titrations are shown in Tables 3 and 4. The maximal neutralization was given by undiluted antiserum against a range of dilutions of the filtrate; the most potent antisera neutralized 250 times the lipolytic titre of the filtrate while dilutions of $1 / 5$ and $1 / 10$ neutralized 60 and 16 times the lipolytic titre of the filtrate, respectively.

No naturally occurring anti-lipolytic antibody was found; the sera were not examined for the presence of any other staphylococcal antitoxin.

\section{DISCUSSION}

Many workers have studied the production of lipase by bacteria and obtained conflicting results. Some used techniques in which only diffusible lipase (exolipase) was demonstrated, while others used methods in which an endolipase, liberated from cells by autolysis or chemical extraction, was being detected as well as exolipase. The production of endolipase may in part explain the so-called 'false positive' results (Turner, 1929) found in the present work when certain media were used. In this reaction the blue colour is most apparent in the centre of the colony, or in streak cultures along the centre of the streak, where presumably the oldest cells are to be found, and autolysis is most likely to occur. This phenomenon may also in part be due to adsorption of the dye by the bacterial cells.

Boiling for at least $\mathbf{4 0} \mathrm{min}$. was required to destroy the lipase activity completely. It is difficult to compare this result with that of MacFarlane \& Knight (1941), who investigated the heat-stability of lecithinase, because experimental conditions were different. It would seem, however, that staphylococcal lipase is relatively stable compared with the majority of enzymes, which are inactivated at $65^{\circ}$, and it belongs rather to the group which includes crystalline trypsin which, in acid solution, is not wholly destroyed by heating at $100^{\circ}$ (Sumner \& Myrbäck, 1950).

The majority of the culture filtrates examined showed only a very slow decline in lipolytic activity during storage at $4^{\circ}$ for 9 months during which time less than $20 \%$ of their lipolytic activity was lost. Those which ceased to be lipolytic had shown a low initial titre, and no detectable lipolytic activity remained in them after storage for 4 weeks.

The cross-neutralization tests carried out with staphylococcal culture filtrates and antisera gave consistent results, and the evidence obtained suggested that the lipases of staphylococci are antigenically homogeneous.

Staphylococcal lipase differed from some of the other bacterial enzymes such as catalase (Campbell \& Fourt, 1939) which have been used as antigens in that neutralization by heterologous antisera was almost, if not entirely, as marked as with homologous antiserum. 


\section{Diffusible lipase of staphylococci}

A search of published literature failed to provide any other recorded experiments in which anti-lipase has been produced as a result of animal injection with culture filtrates containing diffusible lipase. One recorded report was found, however (Gillissen, 1953), in which an anti-lipase was produced by Sartory, Meyer and Lange (1947) with whole cultures of tubercle bacilli. The neutralizing activity of that anti-lipolytic antibody against lipases other than those of tubercle bacilli was investigated with negative results. In the present work no tests were made against any lipase except that of staphylococci.

The author wishes to express her thanks to Prof. Lord Stamp for supervising this work; to Mr E. V. Willmott, F.R.P.S., for taking the photographs, and to the Examiners of London University for permission to publish part of her Thesis.

\section{REFERENCES}

Campbell, D. H. \& Fourt, L. (1939). Immunochemistry of catalase. Amer. J. Biol. $129,385$.

Dolman, C. E. \& Krtching, J. S. (1935). Test for innocuity and antigenic potency of staphylococcal toxoid. J. Path. Bact. 41, 137.

Elliotr, S. D. (1945). Proteolytic enzyme produced by group A streptococei with special reference to its effect on type-specific M-antigen. J. exp. Med. 81, 573.

ELwiot, S. D. (1950). The crystallisation and serological differentiation of a streptococcal proteinase and its precursor. J. exp. Med. 92, 201.

Escherisch, T. (1886). Darmbakterien des Säuglings, p. 158. Stuttgart: Enke.

Grulissen, G. (1953). Ursache und Bedeutung des antimikrobiellen Antagonismus. Zbl. Bakt. (1. Abt. Orig.), 151, 161.

Govan, A. D. T. (1944). Experiments with Nile Blue Sulphate A. J. Path. Bact. 56,447 .

Heatley, N. J. (1944). A method for the assay of penicillin. Biochem. J. 38, 61.

HiLditch, T. P. (1947). Chemical Constitution of Natural Fats. London: Chapman and Hall.

Jensen, L. B. \& Grettie, D. P. (1937). Action of micro-organisms on fats. Food Res. $2,97$.

Kaufmann, C. \& Lehmann, E. (1926). Sind die in der histologischen Technik gebräuchlichen Fettdifferenzierungsmethoden spezifisch? Virchotes Arch. 261, 623.

KNAYSI, G. (1941). On the use of basic dyes for the demonstration of the hydrolysis of fat. J. Bact. 42, 587 .

MacFarlane, M. G. \& KNight, B. C. J. G. (1941). The biochemistry of bacterial toxins. I. The lecithinase activity of $\mathrm{Cl}$. welchii toxins. Biochem. J. 35, 884.

Mackie, T. J. \& McCartney, J. E. (1948). Handbook of Practical Bacteriology, 8th ed. Edinburgh: Livingstone.

Nenckr, M. (1886). UUber die Spaltung der Säureester der Fettreihe u. der aromatischen Verbindungen im Organismus und durch das Pankreas. Arch. exp. Path. Pharmak. 20, 367.

Retrie, T. (1931). A new method of applying Nile Blue sulphate as a fat stain. J. Path. Bact. 34, 595.

Sartory, A., Meyer, J. \& Lange, J. (1947). Étude de l'activité antibiotique 'in vitro' de la Pénicilline sur les bactéries acido-resistantes cultivées en milieux glycérines lipidolytiques. Bull. Acad. Nat. Med. 131, 447.

SumNer, J. B. \& MYrBäCK, K. (1950). The Enzymes, I, part 1. New York: Academic Press Inc.

Turner, R. H. (1929). The action of bacteria on fat. J. infect. Dis. 44, 126. 


\section{EXPLANATION OF PLATE}

Fig. 1. A lipolytic strain of Staphylococcus aureus showing a surrounding area of clearing, on a $48 \mathrm{hr}$. N.F.A. plate. On the other half of the plate (right-hand side) is a strain of Escherichia coli which is not lipolytic and has produced no change in the medium.

Fig. 2. Zones of activity from undiluted culture filtrates of four lipolytic strains of $S$. aureus on N.B.s. agar. The central cylinder contained a heated filtrate, which produced no change in the medium. (The cylinders were removed before taking the photographs.)

Fig. 3. The lipolytic activity of a culture filtrate of $S$. aureus diluted serially up to 1/512: upper left quadrant, filtrate alone; upper right quadrant, filtrate mixed with normal rabbit serum; lower left quadrant, filtrate mixed with immune rabbit serum, undiluted; lower right quadrant, filtrate mixed with immune rabbit serum, diluted 1/10.

(Received 4, January 1954) 
Journal of General Microbiology, Vol. 11, No. 1
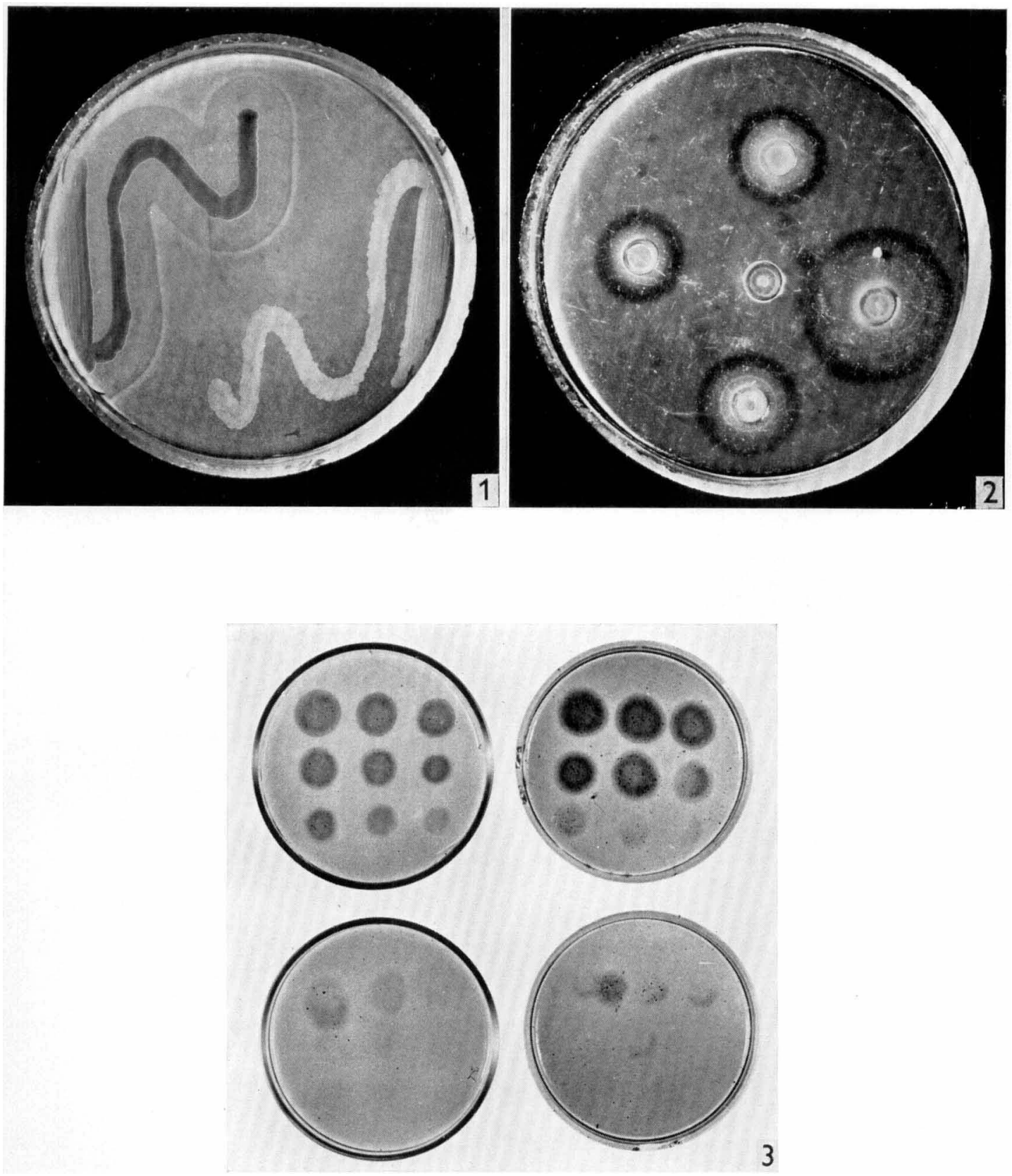

M. DAvies -Diffusible lipase OF STAPHYlococcI 